\title{
Nematodes Associated with Carrot Production in Tasmania, Australia, and the Effect of Pratylenchus crenatus on Yield and Quality of Kuroda-Type Carrot
}

\author{
Frank S. Hay and Sarah J. Pethybridge, Tasmanian Institute of Agricultural Research (TIAR), University of Tas- \\ mania, P.O. Box 3523, Burnie, Tasmania, 7320, Australia
}

\begin{abstract}
Hay, F. S., and Pethybridge, S. J. 2005. Nematodes associated with carrot production in Tasmania, Australia, and the effect of Pratylenchus crenatus on yield and quality of Kuroda-type carrot. Plant Dis. 89:1175-1180.

A survey for nematodes in carrot crops in northern Tasmania detected lesion nematode (Pratylenchus spp.) in 28 of 33 crops, with $P$. crenatus occurring most frequently and P. neglectus, $P$. thornei, and P. penetrans occurring infrequently. Root-knot nematode was detected in five of 33 carrot crops, with Meloidogyne fallax present in two crops. The effect of $P$. crenatus on yield and quality of Kuroda-type carrot was assessed in 42 plots arranged in a $6 \times 7$ lattice in each of two commercial crops. High numbers of $P$. crenatus were recovered from fine roots at 58 days after sowing (DAS). However, following formation of the taproot, low numbers were recovered. In both crops, there was a significant negative correlation between numbers of $P$. crenatus per gram dry weight of root at 58 DAS and the dry weight of root and shoot at 58 DAS. However, the low numbers of $P$. crenatus/g dry weight of root recovered at subsequent sampling times, and the lack of an increase in the number of $P$. crenatus in the soil during the season, suggested that Kuroda-type carrot became resistant to $P$. crenatus following taproot formation. In both crops, $P$. crenatus populations were significantly negatively correlated with plant density and in one crop with average carrot weight. Regression analysis predicted potential yield penalties of 12.1 to $22.3 \mathrm{t} / \mathrm{ha}$ between plots with the highest number of $P$. crenatus and those with none. There was no significant correlation between $P$. crenatus populations during the season and carrot defects. Spatial analysis using Spatial Analysis by Distance Indices determined that $P$. crenatus in soil were significantly aggregated at all times and in roots at 58 DAS were aggregated in one of two trials, with indices of aggregation $\left(I_{a}\right)$ ranging from 1.27 to 1.64 .
\end{abstract}

Carrot is an important vegetable crop in Australia, with some 330,000 tonnes produced annually from approximately 7,500 ha, with a farm-gate value of $\mathrm{A} \$ 150 \mathrm{M}$. In Tasmania, carrot production has increased rapidly in recent years, with 35,000 tonnes produced from 616 ha in the 1999-2000 season (10). Approximately 3,770 tonnes of carrots were exported from Tasmania to other countries in 2000-2001 (13), mainly of Kuroda types to Japan.

Worldwide, plant-parasitic nematodes are a significant constraint to carrot production. More than 90 species from several genera have been associated with umbelliferous crops, including Meloidogyne, Pratylenchus, Longidorus, Paratylenchus, Belonalaimus, Paratrichodorus, Rotylenchus, and Ditylenchus (5). Recently, Hemicycliophora saueri was also associated with carrot defects (31). Diseases caused by root-knot nematode (Meloidogyne spp.) have been traditionally considered to be the most damaging. This genus has been

Corresponding author: F. S. Hay.

E-mail: Frank.Hay@utas.edu.au

Accepted for publication 9 June 2005.

DOI: 10.1094/PD-89-1175

(C) 2005 The American Phytopathological Society associated with forking of the taproot, galls, proliferation of fibrous roots, and stunting (1). Meloidogyne hapla has been shown to cause losses in marketable yield of up to $77 \%$ (2). The main nematodes affecting carrot production in Australia are root-knot (M. hapla and $M$. javanica) and lesion nematodes (Pratylenchus spp.) (10). Root-knot nematode is recognized as a sporadic but serious problem in carrot production in Tasmania and lesion nematode (Pratylenchus spp.) as a potential problem.

The effect of Pratylenchus spp. on carrot in Tasmania is not well known; moreover, there has been little work published on the effect of $P$. crenatus on carrot yield and quality. Potter and Olthof (22) reported $P$. crenatus to cause branched and shortened taproots, death of root tips on side roots, and foliage to be thin and chlorotic. P. crenatus has also been associated with "carrot sickness", exhibited as patches of poorly growing, chlorotic plants with small and often branched main and secondary roots with lesions and dead tips (12). Moreover, Weischer and Brown (32) reported that $600 P$. crenatus per liter of soil were necessary to cause damage to carrots. Other Pratylenchus spp. have also been implicated with reduced yield and quality of carrot. For example, $P$. penetrans has been associated with forking and plant death (4) and reduced size and branching of the taproot (30). Pratylenchus mediterraneus has also been reported to cause seedling death and splitting of the taproot. The application of nematicides for the control of $P$. mediterraneus increased marketable carrot yield by 38 to $45 \%$ (16).

Spatial depiction of nematode populations and temporal changes in density provide basic information on the pathogen dissemination and epidemic structure. Quantifying this information is useful for predicting losses associated with diseases caused by nematodes and the design of effective management strategies. Spatial processes can be visualized on two different scales: at the level of the sampling unit or below by point-pattern based analyses and at the level of sampling unit or above by correlation or geostatistical based analyses $(27,28)$. Several methods of correlation-based analyses have been used to describe the spatial patterns of plantparasitic nematodes as either aggregated or random at specific points in time, while others may also quantify and describe aggregation. Two-term local variance analysis (7) and geostatistics $(23,26)$ are examples of techniques that depict spatial pattern and quantify scale. Both methods have been used for spatial analysis of nematode densities of soybean cyst nematode $(7,8)$. However, spatial patterns have also recently been depicted using the Spatial Analysis by Distance IndicEs (SADIE) method developed by Perry $(17,19)$. SADIE has been used to describe spatial patterns of data based on counts such as weeds (18), insects $(19,34)$, predator-prey relationships (6), and foliar disease $(21,24,25,27)$.

The objectives of this research were to: (i) characterize the plant-parasitic nematodes associated with carrot in Tasmania, Australia, (ii) quantify the relationship between $P$. crenatus and yield and quality of Kuroda carrot varieties, and (iii) quantify spatial patterns of $P$. crenatus in soil and carrot roots.

\section{MATERIALS AND METHODS}

Prevalence and incidence of plantparasitic nematodes. The prevalence and incidence of plant-parasitic nematodes associated with carrot production in 33 fields across northern Tasmania was assessed. Soil samples were gathered within 1 month after emergence of carrots between November 2000 and early February 
2001. All fields were located within a 60standard production practices including irrigation, fertilizer, fungicide, and herbicide applications. In each field, a soil and root sample was taken at approximately 30-m intervals along every tenth bed. Samples were collected with a trowel to a depth of $20 \mathrm{~cm}$. Soil samples were bulked, crumbled to a fine tilth, and mixed. Nematodes were extracted by Whitehead tray method (33) from a $400 \mathrm{~cm}^{3}$ sample and from weighed quantities of roots cut into $1-\mathrm{cm}$ lengths. Soil or roots were placed on tissue suspended in a wire basket in a tray ( $30 \mathrm{~cm}$ long by $20 \mathrm{~cm}$ wide by $3 \mathrm{~cm}$ deep). The tray was filled with water to halfway up the depth of the sample and incubated at room temperature $\left(15\right.$ to $\left.20^{\circ} \mathrm{C}\right)$ for $72 \mathrm{~h}$. The basket was removed from the tray and nematodes retrieved by passing the suspension through a $20-\mu \mathrm{m}$ sieve. Material retained on the sieve was rinsed into a 60$\mathrm{ml}$ container. Water that passed through the sieve was sieved for a second time. Nematodes were allowed to settle overnight $\left(5^{\circ} \mathrm{C}\right)$, and the supernatant was drawn off to leave a suspension of 20 to $30 \mathrm{ml}$. A 4$\mathrm{ml}$ aliquot was placed in a counting dish and nematodes counted and identified to number in the total volume of suspension was then calculated and expressed per 200 $\mathrm{cm}^{3}$ of soil or per gram dry weight of root. Roots were oven dried at $100^{\circ} \mathrm{C}$ for $24 \mathrm{~h}$ following nematode extraction and dry weight recorded.

Subsamples of nematodes from the Pratylenchus, Meloidogyne, and Merlinius genera from 17 crops were sent to Jackie Nobbs of the South Australian Research and Development Institute for identification to species. At least 10 individuals of Pratylenchus spp. from each site were identified to species.

Effect of $P$. crenatus on yield and quality. One field trial was established in each of two seasons (2001 and 20012002), hereafter referred to as 2001 and 2002, respectively. At both sites, P. crenatus was dominant, comprising 90 to $95 \%$ of the Pratylenchus population. Trials were located in fields of carrot on a commercial farm in Penguin, Tasmania $\left(41^{\circ} 11^{\prime} \mathrm{S}\right.$, $\left.146^{\circ} 07^{\prime} \mathrm{E}\right)$ with a long history of vegetable cropping. Carrots had not been grown in either field for 5 years prior to the current crop. The fields were cultivated by $\mathrm{km}$ radius. Each field received similar genus at $\times 50$ to $\times 100$ magnification. The

deep ripping and plowing, and the seed bed prepared by rotary hoe and bed formation. Seed was sown with a precision air seeder. Pesticides and fertilizer were applied as per commercial industry practice and crops watered by overhead traveling gun-type irrigator at 10- to 14-day intervals.

Field trial - 2001. In the first season, the field was sown on 1 January 2001 with a Kuroda-type carrot (var. Koyo II), and the trial was established shortly after emergence on 1 February. The trial consisted of 42 plots arranged in a $6 \times 7$ lattice, each $7 \mathrm{~m}$ long by three beds wide (approximately $5.25 \mathrm{~m}$ ) with each bed having two double rows of carrots. Soil and root samples were obtained on 27 February, 3 April, and 26 April at 58, 93, and 123 days after sowing (DAS), respectively. Samples collected during the season consisted of three carrot plants taken from each of six locations from 2-m sections at each end of the plots. The middle $3-\mathrm{m}$ section of the 7-m-long plots was left unsampled for harvest purposes. Foliage was removed, blotted dry, and fresh weight recorded. Dry weight of foliage was calculated after drying for $24 \mathrm{~h}$ at $100^{\circ} \mathrm{C}$. Roots were washed, blotted dry, and the fresh weight also recorded prior to nematode extraction. For samples collected at 58 DAS, fine roots were chopped into $2-\mathrm{cm}$ sections for extraction, while for those samples collected at 93 and 123 DAS, taproots were halved longitudinally and chopped into 4- to 5-cm lengths for extraction. Nematodes were extracted from roots or a $200 \mathrm{~cm}^{3}$ subsample of soil from each plot by the Whitehead tray technique (33) described previously. Following extraction, roots were oven dried $\left(100^{\circ} \mathrm{C}\right.$ for $\left.24 \mathrm{~h}\right)$ and weighed.

On 3 May (130 DAS), approximately 1 week prior to commercial harvest, the density of plants was assessed in the center 3-m section of each plot by counting the number of plants in 1-m transects taken along three beds. Plots were harvested by digging up 20 plants from each of five double rows from within the 3-m center section of each plot (100 plants per plot). Foliage was removed and discarded. Taproots were washed and graded into categories (0 to 5) using a scale adapted from Belair and Boivin (3): $0=$ no lateral protrusions or stunting; $1=$ taproot with one to two lateral protrusions $<1 \mathrm{~cm}$ long; $2=$

Table 1. Mean, minimum, and maximum numbers of nematode genera per $200 \mathrm{~cm}^{3}$ soil and prevalence from 33 Tasmanian carrot crops up to 5 weeks in age (November 2000 to February 2001)

\begin{tabular}{lcccccc}
\hline & Pratylenchus & Paratylenchus & Stunt $^{\text {a }}$ & $\begin{array}{c}\text { Heterodera } \\
\text { trifolii }\end{array}$ & Meloidogyne $^{\text {Helicotylenchus }}$ \\
\hline Mean $^{\mathrm{b}}$ & 62.5 & 7.8 & 10.6 & 4.7 & 3.8 & 2.9 \\
Minimum & 0 & 0 & 0 & 0 & 0 & 0 \\
Maximum & 313.5 & 20.0 & 38.0 & 8.9 & 8.9 & 2.9 \\
Prevalence & 28 & 8 & 14 & 3 & 5 & 1 \\
\hline
\end{tabular}

a Includes Tylenchorhynchus spp. and Merlinius brevidens.

$\mathrm{b}$ Mean number of nematodes over sites at which a particular genus occurred. taproot with two to three lateral protrusions 1 to $3 \mathrm{~cm}$ long, no stunting; $3=$ taproot with three or more lateral protrusions $>3 \mathrm{~cm}$ long, no stunting; $4=$ taproot with three or more lateral protrusions $>3 \mathrm{~cm}$ long, moderate stunting; and $5=$ taproot with three or more lateral protrusions $>3$ $\mathrm{cm}$ long, severe stunting. Carrots in categories 0 or 1 were considered first grade, suitable for export. Carrots were also further graded into categories of small $(<10$ $\mathrm{cm}$ long, $<2.5 \mathrm{~cm}$ wide), forked, twisted, short cracks $(<2 \mathrm{~cm})$, long cracks $(>2 \mathrm{~cm})$, constricted, and other damage (e.g., insect). Estimated plant density (carrots per ha) was calculated as (mean no. carrots $/ \mathrm{m}$ row $\times \mathrm{m}$ of row per plot)/plot size $\left(\mathrm{m}^{2}\right) \times$ 10,000. Carrot yield (t/ha) was calculated as (weight of carrots in a 100-carrot sample/100 carrots $) \times$ carrots $/$ ha.

Field trial - 2002. The second field trial was established with Kuroda var. Coral II on 23 September 2001. A trial area was selected within an area found to have high numbers of Pratylenchus spp. from soil samples 8 weeks earlier (results not shown). The trial consisted of 42 plots arranged in a $6 \times 7$ lattice. Each plot was 7 $\mathrm{m}$ long by four carrot beds wide (approximately $6.65 \mathrm{~m}$ ), and each bed contained three double-rows of carrots. Soil and plant samples were collected from six positions in each plot on 20 November (58 DAS). Samples consisted of one trowel depth (20 $\mathrm{cm}$ ) of soil and two carrot plants taken at six locations and bulked. Samples were collected from a 2-m section at each end of the plot. The central 3-m section of each plot was left intact for harvest purposes. Nematodes were extracted from a $200 \mathrm{~cm}^{3}$ subsample of soil or roots by the Whitehead tray technique (33) described above. Following extraction, roots and foliage were oven dried $\left(100^{\circ} \mathrm{C}\right.$ for $\left.24 \mathrm{~h}\right)$ and weighed.

Soil and root samples consisting of a trowel depth of soil and one carrot were collected at 116 DAS from six arbitrarily chosen locations at the ends of each plot as described previously. Nematodes were extracted from soil as described above. Carrots were washed and cut in half longitudinally. Half of each carrot was discarded. Carrots were then cut transversely into pieces approximately 0.5 to $2 \mathrm{~cm}$ long $\times 0.2$ to $1 \mathrm{~cm}$ wide with a food processor (Sunbeam Maestro Pro) fitted with a coarse cutting blade. These pieces were then weighed and nematodes extracted by the Whitehead tray technique (33) and recovered by sieving as described previously. After extraction, root tissue was dried $\left(100^{\circ} \mathrm{C} / 24 \mathrm{~h}\right)$ and weights recorded

The trial was harvested on 17 January 2002 (116 DAS), 4 days before commercial harvest. Plant density was recorded by counting the number of carrots in $1-\mathrm{m}$ sections of rows at four arbitrarily chosen locations in the center 3-m section of plots. Twenty carrots were removed from each of 
five arbitrarily chosen locations in the center 3-m section of each plot, bagged, and kept in a coolroom $\left(5^{\circ} \mathrm{C}\right)$ overnight. Carrots were washed and graded into the following categories: forked, carrots with taproot in two sections of approximately equal size; twisted, cracks $>5 \mathrm{~mm}$ wide and $>20 \mathrm{~mm}$ long; splits $<5 \mathrm{~mm}$ wide and $>20 \mathrm{~mm}$ long; bolters, carrots that had formed a seed head; bent; and a 0 to 5 scale adapted from Belair and Boivin (3), as described previously. Carrots in categories $0-1$ were again considered first grade. The length and diameter of these carrots were measured. The weight and number of carrots in each category was also recorded.

Statistical analysis. The relationship between nematode numbers and measured variables was calculated using the Pearson's correlation coefficient $(r)$ and a $t$ test conducted for significance of association. For variables with a significant correlation, linear regression analysis was conducted to describe predictive relationships. All statistical analyses were conducted using Genstat for Windows (Version 5.4.2).

Spatial distribution of $P$. crenatus in carrots fields. The spatial distribution of P. crenatus extracted from soil and roots from each of the plots at each time were analyzed using the SADIE program (Version 1.22) (20). The theory underlying SADIE has been previously described $(17,19)$ and implications discussed $(35,36)$. Briefly, this technique calculates the shortest distances needed to move spatially referenced data to depict "regular" and "crowded" spatial patterns using the same number of sampling units as calculated by a transportation algorithm. For all simulations, the maximum number of 5,967 randomizations was used. These distances are then summed to calculate the overall "distance to regularity, $D$ " and "distance to crowding, $J$ " values. The null hypothesis of no spatial dependence was tested using a one-sided test for aggregation. This is expressed as the index of aggregation, which is equal to the ratio of expected and observed distances to regularity. Values equal to one indicate a random spatial pattern, values less than one suggest a regular pattern, and values greater than one suggest an aggregated pattern $(17,19)$.

\section{RESULTS}

Prevalence and incidence of plantparasitic nematodes. Pratylenchus spp. were the main species associated with carrot crops in northern Tasmania (Table 1). Pratylenchus spp. were present in 28 of 33 carrot crops surveyed and occurred at a mean population density of $62.5 / 200 \mathrm{~cm}^{3}$ of soil in crops in which it was detected (Table 1). Stunt nematodes (Tylenchorhynchus spp. and Merlinius brevidens) occurred in 14 crops in small numbers, at an average density of $10.6 / 200 \mathrm{~cm}^{3}$ of soil (Table 1). Other genera occurred at low densities, on average less than $5 / 200 \mathrm{~cm}^{3}$ of soil in those crops in which they were detected (Table 1). These included Paratylenchus spp. and Helicotylenchus spp. Second-stage juveniles of clover cyst nematode (Heterodera trifolii) were detected in soil from three crops. Low numbers of root-knot nematode (Meloidogyne spp.) were also found in five crops. P. crenatus, $P$. neglectus, $P$. thornei, and $P$. penetrans were confirmed from 14, 4, 2, and 1 of 17 crops, respectively (Table 2). A stunt nematode from one farm was identified as Merlinius brevidens. Second-stage juveniles of Meloidogyne were identified as $M$. fallax from two crops.

Effect of $P$. crenatus on carrot yield and quality in 2001. The number of $P$. crenatus extracted from soil remained similar throughout the season (Table 3). The average number of $P$. crenatus extracted from roots was highest at 58 DAS, but declined at later samplings, with less than one $P$. crenatus/g dry weight of root extracted at 93 and 123 DAS (Table 3). The number of $P$. crenatus/g dry weight root at 58 DAS was significantly negatively correlated with the dry weight of roots per plant $(r=-0.48, P=0.01)$ and foliage per plant $(\mathrm{g})$ at 58 DAS $(r=-0.43$, $P=0.01$ ). The regression equation (Table 4) demonstrated that mean root weight of plants in plots with the highest number of $P$. crenatus (260.6/g dry weight root) was less than half that predicted when no $P$. crenatus were present. At 58 DAS, $P$. crenatus $/ 200 \mathrm{~cm}^{3}$ of soil or in roots or soil at 93 and 123 DAS was not significantly correlated with the dry weight of roots or shoots at 58 DAS.

P. crenatus in roots or soil at any time $(58,93$, or 123 DAS) was not significantly correlated with the fresh weight of carrots

Table 2. Identification of nematode species in 17 carrot fields in Tasmania (2000 to 2001)

\begin{tabular}{|c|c|c|c|c|c|c|}
\hline Location & $\begin{array}{c}\text { Pratylenchus } \\
\text { crenatus }\end{array}$ & $\begin{array}{c}P . \\
\text { neglectus }\end{array}$ & $\begin{array}{c}P . \\
\text { thornei }\end{array}$ & $\begin{array}{c}P . \\
\text { penetrans }\end{array}$ & $\begin{array}{l}\text { Meloidogyne } \\
\text { fallax }\end{array}$ & $\begin{array}{l}\text { Merlinius } \\
\text { brevidens }\end{array}$ \\
\hline Burnie & + & & & & & \\
\hline Cressy & + & & & & & \\
\hline Forth & & + & & & & \\
\hline Heybridge & + & & & & & \\
\hline Kindred & + & & & & & \\
\hline Kindred & + & & & & & \\
\hline Penguin & & + & + & & & \\
\hline Penguin & + & & + & & & \\
\hline Unknown & + & & & & & \\
\hline Sassafras & + & & & & & \\
\hline Sassafras & + & & & & & \\
\hline Somerset & + & & & + & & \\
\hline Sprent & & + & & & + & \\
\hline Sulphur Creek & + & + & & & + & + \\
\hline Preservation Bay & + & & & & & \\
\hline Thirlstane & + & & & & & \\
\hline Wesley Vale & + & & & & & \\
\hline Total fields & 14 & 4 & 2 & 1 & 2 & 1 \\
\hline
\end{tabular}

Table 3. Mean numbers of Pratylenchus crenatus in soil and roots, carrot yield, and plant density (2001)

\begin{tabular}{lcccc}
\hline & Average & Minimum & Maximum & $\begin{array}{c}\text { Standard } \\
\text { deviation }\end{array}$ \\
\hline P. crenatus $/ 200 \mathrm{~cm}^{3}$ soil & & & & \\
58 days after sowing (DAS) & 86.9 & 19.9 & 223.1 & 46.3 \\
93 DAS & 75.6 & 9.2 & 258.4 & 53.2 \\
123 DAS & 80 & 14.8 & 245 & 59.3 \\
P. crenatus /g dry weight root & & & & \\
58 DAS & 99.3 & 0 & 260.6 & 75.8 \\
93 DAS & 0.02 & 0 & 0.2 & 0.04 \\
123 DAS & 0.02 & 0 & 0.36 & 0.06 \\
Plant density $\left(/ \mathrm{m}^{2}\right)$ & 42.2 & 32.8 & 52.2 & 4.7 \\
Yield of carrot $(\mathrm{t} / \mathrm{ha})$ & 53.1 & 39.6 & 70.4 & 7.7 \\
First-grade carrot $(\%$ by weight) & 71.8 & 51.8 & 86.9 & 9.4 \\
\hline
\end{tabular}

Table 4. Linear regression analysis between numbers of Pratylenchus crenatus extracted from tissue and soil at 58 days after sowing (DAS), and from soil at 123 DAS and yield and quality of Kuroda carrot (2001)

\begin{tabular}{|c|c|c|}
\hline \multicolumn{3}{|l|}{ P. crenatus/g dry weight root at 58 DAS } \\
\hline Dry weight of roots/plant (58 DAS) & $Y=0.2469-0.0005 X$ & $P=0.002$, adjusted $R^{2}=0.21$ \\
\hline Dry weight of foliage/plant (58 DAS) & $Y=0.7669-0.0008 X$ & $P=0.08$, adjusted $R^{2}=0.15$ \\
\hline \multicolumn{3}{|l|}{ P. crenatus $/ 200 \mathrm{~cm}^{3}$ soil at 58 DAS } \\
\hline Carrots/ha (123 DAS) & $Y=44.75^{*} 10^{6}-388.91 X$ & $P=0.01$, adjusted $R^{2}=0.14$ \\
\hline Yield (t/ha) (123 DAS) & $Y=55.976-0.0542 X$ & $P=0.02$, adjusted $R^{2}=0.10$ \\
\hline
\end{tabular}


$(n=100)$ from each plot, weight in categories $0-1,2-5$, or any of the abnormal categories, or in the average weight of a carrot, or average weight of a carrot in categories $0-1,2-5$ at harvest (130 DAS). This suggested that $P$. crenatus had not contributed to stunting of carrot or abnormalities in this trial.

P. crenatus extracted from soil at 58 DAS was significantly correlated with plant density at harvest $(r=-0.42, P=$ 0.01 ), and with estimated yield potential

(t/ha) $(r=-0.39, P=0.05)$. A regression between numbers of $P$. crenatus extracted from soil at 58 DAS and potential plot yield ( $\mathrm{t} / \mathrm{ha}$ ) at harvest (Table 4) predicted yields of 56.0 and 43.9 t/ha at population densities of zero and the maximum density recorded $\left(223 P\right.$. crenatus $/ 200 \mathrm{~cm}^{3}$ soil), respectively, a difference of $12.1 \mathrm{t} / \mathrm{ha}$. $P$. crenatus in roots or shoots at other times was not significantly correlated with plant density or estimated yield potential at harvest.

Table 5. Mean numbers of Pratylenchus crenatus in soil or roots, carrot yield, and plant density (2002)

\begin{tabular}{lcccc}
\hline & Average & Minimum & Maximum & $\begin{array}{c}\text { Standard } \\
\text { deviation }\end{array}$ \\
\hline P. crenatus/200 cm ${ }^{3}$ soil & & & & \\
58 days after sowing (DAS) & 119.2 & 10.1 & 354.4 & 73.4 \\
116 DAS & 76 & 0 & 220 & 51.3 \\
$P$. crenatus/g dry weight root & 734.0 & 200.8 & $1,455.0$ & 352.2 \\
58 DAS & 0.11 & 0 & 0.61 & 0.17 \\
116 DAS & 55.3 & 44.3 & 72.3 & 6.2 \\
Plant density $\left(/ \mathrm{m}^{2}\right)$ & 62.6 & 42.2 & 83.4 & 10.1 \\
Yield of carrot $(\mathrm{t} / \mathrm{ha})$ & 80.7 & 64.4 & 90.8 & 6 \\
First-grade carrot $(\%$ by weight) & & &
\end{tabular}

Table 6. Pearson's correlation coefficients $(r)$ and probability levels in parentheses $(P)$ between Pratylenchus crenatus populations at 58 days after sowing (DAS) and yield and quality attributes of Kuroda carrot at two sampling dates in 2002

\begin{tabular}{lcc}
\hline & $\begin{array}{c}\boldsymbol{P .} \text { crenatus/ } \\
\mathbf{2 0 0} \mathbf{~ c m}^{\mathbf{3}} \text { soil }\end{array}$ & $\begin{array}{c}\boldsymbol{P} \text { crenatus/ } \\
\text { g dry weight root }\end{array}$ \\
\hline 58 DAS & & \\
Dry weight of foliage/plant (g) & $\mathrm{ns}$ & $-0.45(0.05)$ \\
Dry weight of root/plant (g) & $\mathrm{ns}$ & $-0.48(0.05)$ \\
116 DAS & $\mathrm{ns}$ & $-0.4(0.01)$ \\
Fresh weight (all categories) & $\mathrm{ns}$ & $\mathrm{ns}$ \\
Fresh weight (categories 0-1) & $-0.36(0.05)$ & $-0.31(0.05)$ \\
Fresh weight (categories 2-5) & $\mathrm{ns}$ & $\mathrm{ns}$ \\
Fresh weight (abnormal ${ }^{\mathrm{a}}$ ) & $\mathrm{ns}$ & $-0.36(0.05)$ \\
Average individual carrot weight (categories 0-1) & $\mathrm{ns}$ & $\mathrm{ns}$ \\
Average individual carrot weight (categories 2-5) & $\mathrm{ns}$ & $-0.36(0.05)$ \\
Average individual carrot weight (all categories) & $\mathrm{ns}$ & $-0.47(0.05)$ \\
Average carrot length (categories 0-1) & $-0.44(0.05)$ & $-0.38(0.05)$ \\
Plant density (/ha) & $-0.35(0.05)$ & $-0.53(0.01)$ \\
Yield (t/ha) & $\mathrm{ns}$ & $-0.43(0.01)$ \\
Yield (categories 0-1) (t/ha) & $-0.41(0.01)$ & $-0.36(0.05)$ \\
Yield (categories 2-5) (t/ha) & &
\end{tabular}

a $\mathrm{ns}=$ not significant.

${ }^{\mathrm{b}}$ Abnormal categories include forked, twisted, cracks of at least $5 \mathrm{~mm}$, bolters, and bent.

Table 7. Linear regression analysis between numbers of Pratylenchus crenatus extracted from roots and soil at 58 days after sowing (DAS), and soil at 116 DAS, and yield and quality of Kuroda carrot (2002)

\begin{tabular}{lll}
\hline $\begin{array}{l}P . \text { crenatus } / 200 \mathrm{~cm}^{3} \text { soil at 58 DAS } \\
\text { Yield (t/ha) (116 DAS) }\end{array}$ & $Y=65.09+-0.045 X$ & $P=0.002$, adjusted $R^{2}=0.19$ \\
$\begin{array}{l}P . \text { crenatus } / \mathrm{g} \text { dry weight root at 58 DAS } \\
\begin{array}{c}\text { Dry weight (g) of foliage/plant } \\
\text { (58 DAS) }\end{array}\end{array}$ & $Y=0.226+-0.0001 X$ & $P=0.008$, adjusted $R^{2}=0.15$ \\
$\begin{array}{c}\text { Dry weight (g) of roots/plant } \\
\text { (58 DAS) }\end{array}$ & $Y=0.040+-1.41^{*} 10^{-5} X$ & $P=0.002$, adjusted $R^{2}=0.21$ \\
$\begin{array}{c}\text { Fresh weight (g) of } 100 \text { carrots } \\
\text { (116 DAS) }\end{array}$ & $Y=12,058.88+-1.29 X$ & $P=0.01$, adjusted $R^{2}=0.13$ \\
$\begin{array}{c}\text { Mean length (cm) of a carrot } \\
\text { in first grade categories (116 DAS) }\end{array}$ & $Y=160.36+-0.008 X$ & $P=0.002$, adjusted $R^{2}=0.19$ \\
$\begin{array}{c}\text { Mean weight (g) of carrot } \\
\text { in first grade categories (116 DAS) }\end{array}$ & $Y=117.6+-0.01 X$ & $P=0.03$, adjusted $R^{2}=0.10$ \\
$\begin{array}{c}\text { Mean weight (g) of all carrots } \\
\text { (116 DAS) }\end{array}$ & $Y=117.32+-0.01 X$ & $P=0.03$, adjusted $R^{2}=0.10$ \\
\begin{tabular}{l} 
Potential plot yield (t/ha) (116 DAS) \\
\hline
\end{tabular} & $Y=73.802+-0.0153 X$ & $P=0.0003$, adjusted $R^{2}=0.267$ \\
\hline
\end{tabular}

Effect of $P$. crenatus on carrot yield and quality in 2002. Similar numbers of P. crenatus were recovered from soil at 58 and 116 DAS (Table 5). However, greater numbers of $P$. crenatus/g dry weight of root were extracted at 58 DAS in comparison to 116 DAS (Table 5). Low numbers of Paratylenchus sp. were also present in soil (results not shown). The number of $P$. crenatus in roots, but not soil, at 58 DAS was negatively correlated with the dry weights of foliage and roots per plant at 58 DAS (Table 6). Regression analysis (Table 7) demonstrated that the average weight of roots per plant at the maximum number of $P$. crenatus $(1,455 / \mathrm{g}$ dry weight of root) was less than half the weight of roots predicted in the absence of $P$. crenatus (Table 7). P. crenatus in roots at 58 DAS were negatively correlated with the fresh weight of 100 carrots sampled from each plot, weight of carrots in categories 2-5, and average carrot weight and length (Table 6). $P$. crenatus in soil at 58 DAS was negatively correlated with the weight of carrots in categories 2-5 (Table 6).

$P$. crenatus in roots and soil at 58 DAS were negatively correlated with plant density at harvest, estimated yield of carrots $(\mathrm{t} / \mathrm{ha})$, and estimated yield of carrots in category 2-5 (t/ha) (Table 6). In addition, numbers of $P$. crenatus in roots at 58 DAS were negatively correlated with estimated yield (t/ha) in category 0-1 (Table 6). Linear regression analysis predicted total yields of 65.1 and $49.2 \mathrm{t} / \mathrm{ha}$ at zero and $354.4 P$. crenatus $/ 200 \mathrm{~cm}^{3}$ soil, respectively (the maximum number recorded in this trial), a difference of 15.9 t/ha (Table 7). Similarly, linear regression analysis predicted yields of 73.8 and $51.5 \mathrm{t} / \mathrm{ha}$ at zero and 1,455 P. crenatus/g dry weight of root, respectively, a difference of $22.3 \mathrm{t} / \mathrm{ha}$ (Table 7). P. crenatus in soil or roots at 116 DAS was not significantly correlated with any of the measured yield or quality variables listed (Table 6).

Spatial distribution of $P$. crenatus in carrot fields. According to SADIE, the distribution of $P$. crenatus extracted from soil in fields in both seasons was significantly aggregated at all times after planting (Table 8). The distribution of $P$. crenatus extracted from roots at 58 DAS was random in the trial conducted in 2001, while in the trial conducted the following year, it was significantly aggregated (Table 8).

\section{DISCUSSION}

This research has provided new quantitative information concerning the distribution of plant-parasitic nematodes associated with carrot production and the effect and spatial distribution of $P$. crenatus on commonly used carrot varieties in Tasmania. Pratylenchus spp. (especially P. crenatus) was the most common lesion nematode occurring in carrot crops in northern Tasmania. This species is also common in pyrethrum crops in Tasmania (9). Root- 
knot nematode occurred infrequently in carrot crops. Meloidogyne hapla and $M$. arenaria have been reported from Tasmania (14); however, this is the first report of M. fallax. M. fallax was first described from the Netherlands $(11,29)$ and has recently been reported from South Australia (15). It is thought this nematode has been in Australia for many years and is likely to be widespread. The nematode can be particularly damaging to carrot and potato crops at high population densities (15).

In this study, numbers of $P$. crenatus were not associated with defects of the taproot in either trial. This may indicate that Kuroda types of carrot have a different response to feeding by lesion nematode than that described for other carrot types in other studies $(22,32)$. The main impact of $P$. crenatus on Kuroda carrot was at the early stages of seedling emergence and growth. In both trials, high numbers of $P$. crenatus were recovered from roots at 58 DAS and were correlated with reduced foliage and root growth at this stage. The significant negative relationship between $P$. crenatus populations at 58 DAS and plant density at harvest in both trials suggested that $P$. crenatus contributed to seedling death, as was noted by Orion et al. (16) for P. mediterraneus. Beyond $58 \mathrm{DAS}$, there was poor recovery of $P$. crenatus from roots in either year. The rapid growth of the taproot later in the season would have reduced the number extracted per gram of root. However, the finding that $P$. crenatus populations in the soil did not increase over the life of the crop suggested poor multiplication of $P$. crenatus during the season, and that Kuroda carrot may become resistant to nematode feeding with age. Further work is required to assess the multiplication rate of $P$. crenatus on different carrot varieties. P. crenatus at 58 DAS were negatively correlated with average carrot weight in 2002 (but not in 2001), suggesting that nematode feeding early in the season could reduce carrot size at harvest. The discrepancy between the two trials is probably due to the greater range of nematode population densities of $P$.

Table 8. Analysis of the spatial distribution of Pratylenchus crenatus extracted from soil and roots in carrot fields in 2001 and 2002 using SADIE $^{\mathrm{a}}$

\begin{tabular}{lrl}
\hline & $\boldsymbol{I}_{\boldsymbol{a}}$ & \multicolumn{1}{c}{$\boldsymbol{P}$} \\
\hline 2001 & & \\
Root 58 DAS & 1.213 & 0.104 \\
Soil 58 DAS & 1.528 & 0.008 \\
Soil 93 DAS & 1.643 & 0.002 \\
Soil 123 DAS & 1.595 & 0.003 \\
2002 & & \\
Root 58 DAS & 1.446 & 0.018 \\
Soil 58 DAS & 1.268 & 0.07 \\
Soil 116 DAS & 1.629 & 0.003 \\
\hline
\end{tabular}

${ }^{\text {a }}$ SADIE $=$ spatial analysis by distance indices; $I_{a}=$ index of aggregation derived from SADIE analysis; DAS = days after sowing. crenatus per gram roots at 58 DAS in the trial in 2002 in comparison to 2001. $P$. crenatus at 58 DAS extracted from either soil or roots was negatively correlated with potential plot yield and yield of first-grade carrots in both trials. Linear regression analysis determined potential yield differences between those plots with the highest number of $P$. crenatus in comparison to those with none ranging from $12.1 \mathrm{t} / \mathrm{ha}$ (2001) to $22.3 \mathrm{t} / \mathrm{ha}$ (2002).

The strong spatial dependence of $P$. crenatus extracted from soil and roots demonstrated in both trials is typical of the patchy distribution of nematodes described by several investigators $(7,8)$ and emphasizes the need for intensive sampling of fields to gain a reliable measure of nematode numbers prior to planting. Identifying areas where nematode numbers are high may also give growers flexibility for the application of nematicides in high risk areas.

We have been able to describe the spectrum of plant-parasitic nematodes associated with carrot production in Tasmania, Australia, and attribute the main effect of $P$. crenatus on Kuroda types of carrot to seedling death. Future research will aim at identifying resistant carrot varieties and alternative crops that can be used in rotation to reduce nematode numbers and hence the risk of disease.

\section{ACKNOWLEDGMENTS}

We gratefully acknowledge financial support by Aus Veg levy and the Commonwealth Government through Horticulture Australia Ltd., assistance with identification of nematodes by Jackie Nobbs (SARDI), technical assistance of L. Whelan and C. Whiteroad, and cooperation of Simplot Australia Pty. Ltd., Field Fresh Tasmania, Forth Farm Produce, and Emara Nominees.

\section{LITERATURE CITED}

1. Abawi, G. S., Ludwig, J. W., and Fusco, L. 1997. Symptoms and damage of the northern root-knot nematode on carrots in New York. (Abstr.) Phytopathology 87:S1.

2. Abawi, G. S., Ludwig, J. W., and Carroll, J. 2001. Management of leaf blight diseases and root-knot nematode on carrots in New York. Pages 72-73 in: Great Lakes Expo Fruit, Vegetable and Farm Market. Education Session Abstracts. R. C. Brook, ed. Michigan State University Extension, East Lansing.

3. Belair, G., and Boivin, G. 1988. Spatial pattern and sequential sampling plan for Meloidogyne hapla in muck-grown carrots. Phytopathology 78:604-607.

4. Coosemans, J. 1975. The influence of Pratylenchus penetrans on growth of Impatiens balsamina L., Daucus carota L., Linen usitatissimum L., and Chrysanthemum indicum L. Meded. Fac. Landbouwwet. Univ. Gent. 40:465-471.

5. Davis, R. M., and Raid, R. N. 2002. Compendium of Umbelliferous Crop Diseases. American Phytopathological Society, St. Paul, MN.

6. Ferguson, A. W., Williams, I. H., Klukowski, Z., Walczak, B., and Perry, J. N. 1999. Spatial population dynamics of a pest and its parasitoid in an oilseed rape crop. Asp. Appl. Biol. 53:143-148.

7. Francl, L. J. 1986. Spatial analysis of Heterodera glycines populations in field plots. J. Nematol. 18:183-189.

8. Gavassoni, W. L., Tylka, G. L., and Munkvold,
G. P. 2001. Relationships between tillage and spatial patterns of Heterodera glycines. Phytopathology 91:534-545.

9. Hay, F. S., Stirling, G. R., and Chung, B. 2001. Plant-parasitic nematodes associated with pyrethrum in Tasmania. Page 208 in: Proc. Bienn. Plant Pathol. Conf., 13th. Australas. Plant Pathol. Soc.

10. Hay, F. S., Walker, G., Davison, E., McKay, A. Pattison, T., Cobon, J., Stanton, J., Keating, D., Nambier, L., and Nobbs, J. 2004. Improved control of nematodes in carrot production. Page 207 in: Final Report for Project VG99020. Horticulture Australia Ltd., Sydney, NSW.

11. Karssen, G. 1996. Description of Meloidogyne fallax n. sp. (Nematode: Heteroderidae), a root knot nematode from the Netherlands. Fundam. Appl. Nematol. 19:593-599.

12. Loof, P. A. A. 1991. The family Pratylenchidae Thorne, 1949. Pages 363-421 in: Manual of Agricultural Nematology. W. R. Nickle, ed. Marcel Dekker Inc., New York.

13. McKay, A. 2004. WA experts in exporting carrots. Good Fruit Vegetables 14:29-32.

14. Nobbs J. M. 2003. Plant parasitic nematodes of Australian vegetables and related species. Horticulture Australia Ltd., Project no. VG98102.

15. Nobbs, J. M., Liu, Q., Hartley, D., Handoo, Z., Williamson, V. M., Taylor, S., Walker, G., and Curran, J. 2001. First record of Meloidogyne fallax in Australia. Australas. Plant Pathol. 30:373.

16. Orion, D., Shelvin, E., and Yaniv, A. 1988. Controlling the migratory nematode Pratylenchus mediterraneus improves carrot yield and quality. Hassadh 69:72-74.

17. Perry, J. N. 1995. Spatial analysis by distance indices. J. Anim. Ecol. 64:303-314.

18. Perry, J. N. 1997. Some aspects of the spatial dynamics of weeds. Pages 625-628 in: Proc. 1997 Brighton Conf.: Weeds, Vol. 2: 7B-4. British Crop Protection Council, Farnham, Surrey, UK

19. Perry, J. N. 1998. Measures of spatial pattern for counts. Ecology 79:1008-1017.

20. Perry, J. N., Bell, E. D., Smith, R. H., and Woiwod, I. P. 1996. SADIE: Software to Measure and Model Spatial Pattern. Asp. Appl. Biol. 46:95-102.

21. Pethybridge, S. J., Esker, P., Hay, F., Wilson, C., and Nutter, F. W., Jr. 2005. Spatiotemporal description of epidemics caused by Phoma ligulicola in Tasmanian pyrethrum fields. Phytopathology 95:648-658.

22. Potter, J. W., and Olthof, Th. H. A. 1993. Nematode pests of vegetable crops. Pages 171 207 in: Plant Parasitic Nematodes in Temperate Agriculture. K. Evans, D. L. Trudgill, and J. M. Webster, eds. CAB International, Wallingford, England.

23. Rossi, R. E., Mulla, D. J., Journel, A. G., and Franz, E. H. 1992. Geostatistical tools for modelling and interpreting ecological spatial dependence. Ecol. Monogr. 62:277-314.

24. Scott, J. B., Hay, F. S., Wilson, C. R., Cotterill, P. J., and Fist, A. J. 2003. Spatiotemporal analysis of epiphytotics of downy mildew of oilseed poppy in Tasmania, Australia. Phytopathology 93:752-757.

25. Shah, D. A., Bergstrom, G. C., and Ueng, P. P. 2001. Foci of Stagnospora nodorum blotch in winter wheat before canopy development. Phytopathology 91:642-647.

26. Trangmar, B. B., Yost, R. S., and Uehara, G. 1985. Applications of geostatistics to spatial studies of soil properties. Adv. Agron. 38:4594.

27. Turechek, W. W., and Madden, L. V. 1999. Spatial pattern analysis of strawberry leaf blight in perennial production systems. Phytopathology 89:421-433.

28. Turechek, W. W., and Madden, L. V. 1999. 
Spatial pattern analysis and sequential sampling for the incidence of leaf spot on strawberry in Ohio. Plant Dis. 83:992-1000.

29. van der Beek, J. G., Folkertsma, R., Poleij, L. M., van Koert, P. H. G., and Bakker, J. 1997. Molecular evidence that Meloidogyne hapla, $M$. chitwoodi, and M. fallax are distinct biological entities. Fundam. Appl. Nematol. 20:513-520.

30. Vrain, T. C., and Belair, G. 1981. Symptoms induced by the lesion nematode, Pratylenchus penetrans on carrot taproots in organic soil.
Phytoprotection 62:79-81.

31. Walker, G. E. 2004. Associations between carrot defects and nematodes in South Australia. Australas. Plant Pathol. 33:579-584.

32. Weischer, B., and Brown, D. J. F. 2000. An introduction to nematodes. Page 49 in: General Nematology, A Students' Textbook. Pensoft Sofia Moscow.

33. Whitehead, A. G., and Hemming, J. R. 1965. A comparison of some quantitative methods of extracting small vermiform nematodes from soil. Ann. Appl. Biol. 55:25-38.
34. Winder, L., Perry, J. N., and Holland, J. M. 1999. The spatial and temporal distribution of the grain aphid Sitobion avenae in winter wheat. Entomol. Exp. Appl. 93:277-290.

35. Xu, X.-M., and Madden, L. V. 2003. Considerations for the use of SADIE statistics to quantify spatial patterns. Ecography 26:821830.

36. Xu, X.-M., and Madden, L. V. 2004. Use of SADIE statistics to study spatial dynamics of plant disease epidemics. Plant Pathol. 53:38-49. 